University for Business and Technology in Kosovo

UBT Knowledge Center

UBT International Conference

2015 UBT International Conference

Nov 7th, 9:00 AM - 5:00 PM

\title{
Imperfection impact on behavior of the secondary nonstructural elements and vertical non precise erection of members
}

\author{
Armend Mujaj \\ Polytechnic University of Tirana, armend20mujaj@gmail.com \\ Florim Grajçevci \\ University of Prishtina, florim.grajcevci@uni-pr.edu \\ Driton R. Kryeziu \\ Polytechnic University of Tirana, driton_kryeziu@yahoo.com \\ Zijadin Guri \\ University og Skopje, guri.zijadin@gmail.com \\ Fisnik Kadiu \\ Polytechnic University of Tirana, kadiufisnik@gmail.com
}

Follow this and additional works at: https://knowledgecenter.ubt-uni.net/conference

Part of the Civil Engineering Commons, and the Structural Engineering Commons

\section{Recommended Citation}

Mujaj, Armend; Grajçevci, Florim; Kryeziu, Driton R.; Guri, Zijadin; and Kadiu, Fisnik, "Imperfection impact on behavior of the secondary nonstructural elements and vertical non precise erection of members" (2015). UBT International Conference. 74.

https://knowledgecenter.ubt-uni.net/conference/2015/all-events/74

This Event is brought to you for free and open access by the Publication and Journals at UBT Knowledge Center. It has been accepted for inclusion in UBT International Conference by an authorized administrator of UBT Knowledge Center. For more information, please contact knowledge.center@ubt-uni.net. 


\title{
Imperfection impact on behavior of the secondary nonstructural elements and vertical non precise erection of members
}

\author{
Armend Mujaj ${ }^{1}$, Florim Grajçevci ${ }^{2}$, Driton R. Kryeziu ${ }^{3}$, Zijadin Guri ${ }^{4}$, Fisnik Kadiu ${ }^{5}$ \\ 1 Politechnical University Faculty of Civil Engineering in Tirana, \\ 2 Univeristy of Prishtina, "Faculty of Civil Engineering and Architecture", \\ 3Politechnical University" Faculty of Civil Engineering in Tirana, \\ 4 University, Faculty of Civil Engineering in Skopje, \\ 5 Politechnical University of Tirana, Faculty of CE \\ armend20mujaj@gmail.com1, florim.grajcevci@uni-pr.edu2 \\ driton_kryeziu@yahoo.com3, guri.zijadin@gmail.com4, kadiufisnik@gmail.com5
}

\begin{abstract}
In this paper of works will be try to present the fundamental computation referring to the imperfection impacts phenomena of non-precise erection effects of the structural members as are vertical columns. Depends from the structural type, the structure should have a vertical structural members with the enough vertical and shear capacity provoked from horizontal action of earthquake, wind, dead and imposed vertical loads. The structural designers, during the structural computation are improve the several ap proximations creating the dy namic modeling, having into the consideration of structural elements classification in the prior and secondary structural elements. It is very none that the structural vertical elements have a designed capacity from the horizont al actions, the nonstructural elements has the indirect impact on the structural behavior at all. Also the non-precise erection phenomena or imperfection of the vertical structural members is very important in the structural behavior.
\end{abstract}

Key Words: Structure, nonstructural elements, non-precise erection - imperfection.

\section{Introduction}

Upon dealing with the designing of structural elements, based on best designing practices, without having into consideration the type of the material, its destination and stories (floors), it has do go through some phases which are in a way connected to each other. As the first phase has to do with the structural concept, the second phase deals with the static-dy namic analy sis of the structure, the third phase deals with the dimensioning of comprised elements, usually the fourth one shows the details of elements and its verification. During the first phase, the designers mostly do the preliminary calculation by adopting dy namic calculation models, in a way that to do the dimensioning of structure elements. Within these calculation models are mainly taken into account the supporting elements, and not those that are treated as secondary elements - constructive. In this paper mainly is going to be treated the secondary elements (constructive) on the behavior and reaction of structures in general. Upon dealing with structures, especially with vertical load of high intensity, the issue of imperfection should be taken seriously into consideration as for dealing with single isolated elements, such as columns, and to those that are combined with each other, portal frames.

According to EN 1992-1-1 for single isolated column or portal frame under vertical load, imperfection can be expressed by supposing that the structure or its elements gets a deformation by creating an angle $\theta$ in respect to vertical axis, as shown below:

$$
\theta_{\mathrm{i}}=\theta_{\mathrm{o}} \cdot \alpha_{\mathrm{h}} \cdot \alpha_{\mathrm{m}}=\frac{1}{200} \cdot \frac{2}{\sqrt{\mathrm{H}}} \cdot \sqrt{0,50\left(1+\frac{1}{\mathrm{n}^{\prime}}\right)}
$$

(1) 
$\theta_{0}$ - represents the base value that is recommended to be $1 / 200$, but it can also be as a part of coefficients determined by National Annexes,

$\theta_{\mathrm{h}}$ - represents a reduction factor which is in the function of column height or portal frame and has the values $2 / 3 \leq \theta_{\mathrm{h}} \leq 1,0$,

$\theta_{\mathrm{m}}$ - represents a factor of reduction for the number of elements,

$\mathrm{H}$ - the height of elements that are taken into consideration (columns or portal frames),

n'- represents the number of vertical elements that do contribute on the effect of imperfection.

In Figure 1 is shown the way of calculation upon the effect of imperfection on the single vertical structural elements, such as columns, respectively the calculation of horizontal component from the action of vertical loads.

The phenomena of imperfection can be calculated even for elements that are parts of the structure whereby in the Figure 2 will be represented three models and the way of its treatment for imperfection. The effect of vertical load upon the structure which shows the bending moment and rotation moment could be substituted with equivalent forces in multiple floor structure where its imperfection could be approximated by adding in every level of floors one horizontal force, as it is shown in the Figure 2, whereby their values can be calculated with the formula as it is shown below:

$$
\mathrm{H}_{\mathrm{i}}=\frac{\mathrm{V}_{\mathrm{k}} \cdot \Delta_{\mathrm{i}}}{\mathrm{H}_{\text {story }}}=\mathrm{V}_{\mathrm{k}} \cdot \theta_{\mathrm{i}} \quad \mathrm{k}=1,2,3 \ldots
$$

where:

$\mathrm{V}_{\mathrm{k}}$ - is the total load of one floor in the structure

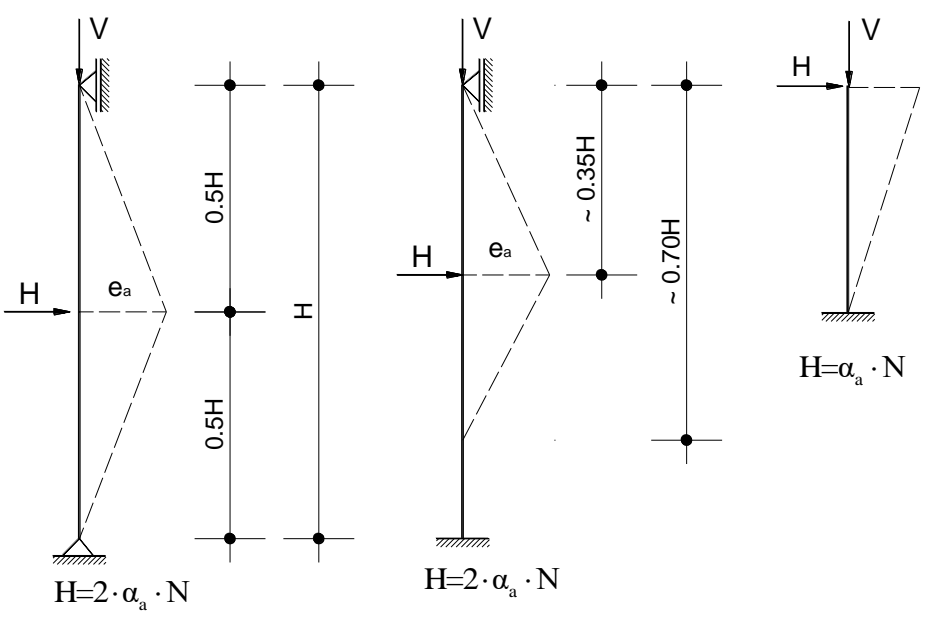

Figure 1. The presentation of horizontal load from the action of vertical loads as a result of imperfection upon the elements of the structure. 


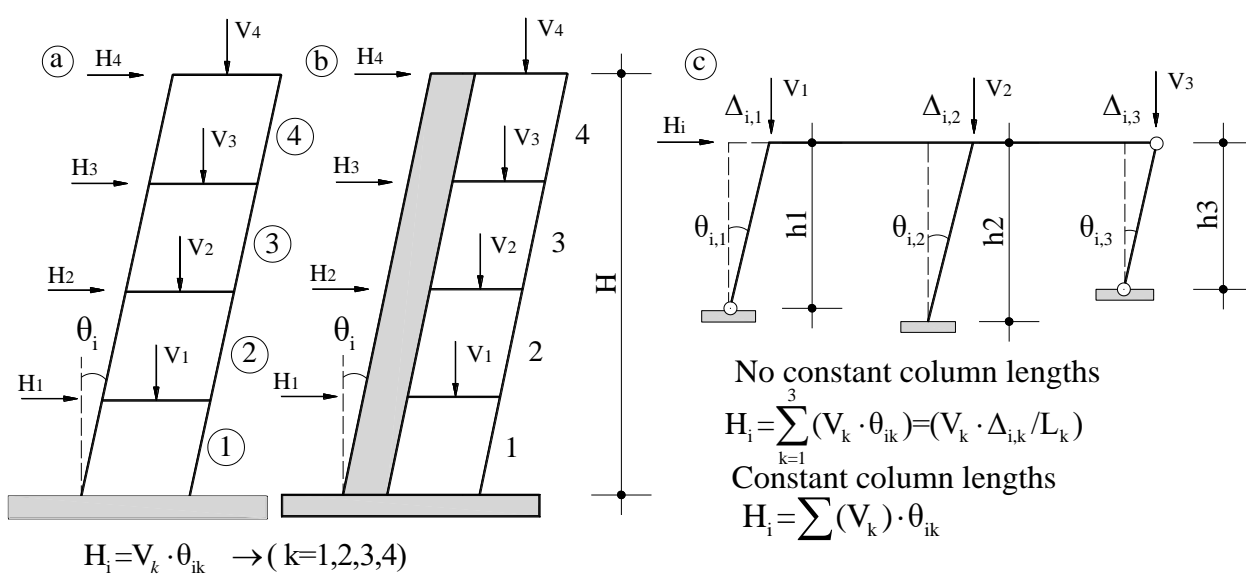

Figure 2. Types of structures with vertical loads and the determination of its imperfection a) the structure type of portal frame, b) combined structure and c) portal frame structure with two spans

Structures without stiffness elements could be treated as non-moveable construction joints if every element (column) holds more than $70 \%$ of the central average force $N_{E d, m}$, which is calculated with the formula as shown below:

$$
\begin{array}{ll} 
& \mathrm{N}_{\mathrm{Edm}}=0,70 \cdot \sum \frac{\mathrm{V}_{\mathrm{Ed}}}{\mathrm{n}} \\
& \sum \mathrm{V}_{\mathrm{Ed}}=\sum \mathrm{G}_{\mathrm{Ed}}+\sum \mathrm{Q}_{\mathrm{Ed}} \\
\mathrm{n} & \text { - the number of vertical elements of the structure including columns and walls, } \\
\mathrm{G}_{\mathrm{Ed}} & \text { - the sum of vertical loads calculated as dead load, } \\
\mathrm{Q}_{\mathrm{Ed}} & \text { - the sum of horizontal loads calculated as live load. }
\end{array}
$$

Point 4.2.2 (4) of EN-1988-1, suggest that the total contribution of all secondary seismic elements (constructive), on the side rigidity shall not exceed the value $15 \%$ of the contribution of all primary seismic elements.

$$
\frac{\rho_{\mathrm{w}}}{\rho_{\mathrm{MR}}}=\frac{\mathrm{K}_{\mathrm{MR}}}{\mathrm{K}_{\mathrm{w}}} \leq 15 \%
$$

\section{Nume rical part}

To better analyze the phenomena of imperfection in Figure 3 it shown the multistory object $\mathrm{P}+14$, with residential destination. The height of all floors is $\mathrm{h}=300 \mathrm{~cm}$. The elements that are about to be taken into consideration are the secondary vertical construction elements towards its reaction of imperfection phenomena. During the analy sis of the given structure, in order to absorb the horizontal loads from seismic movements, for our analy sis are taken into account only the vertical elements, as it is shown in the Figure 3, that are walls W-1, W-2 and W-3, and the effect of imperfection by vertical loads it is not taken into consideration. 

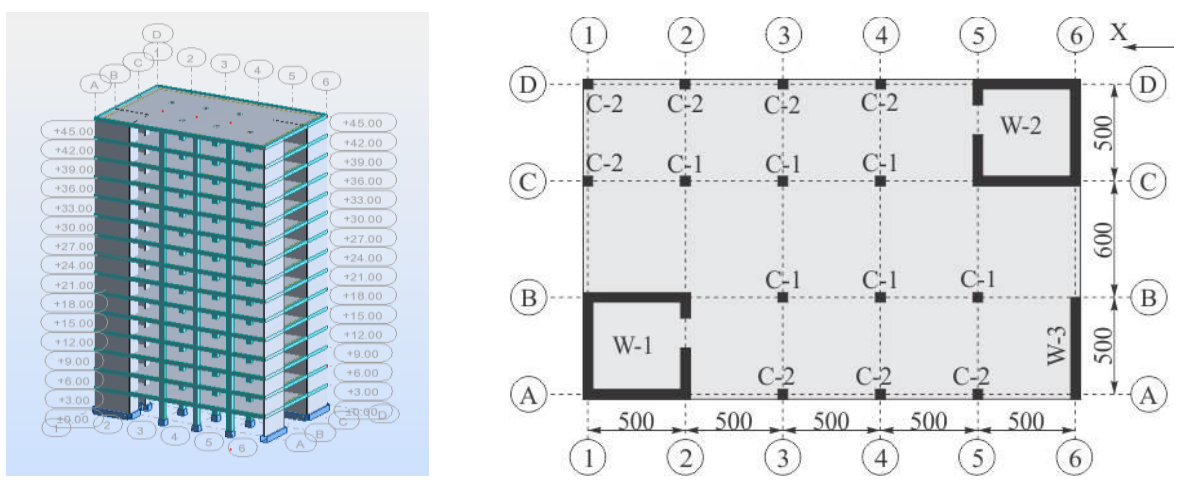

Figure 3. Plan and the view of analy zed structure

Table 1. The material quality use the structure

\begin{tabular}{|c|c|c|}
\hline Analysis & Statics & Seismic \\
\hline $\begin{array}{l}\text { Concrete } \\
\text { C } 30 / 37\end{array}$ & $\begin{array}{l}\mathrm{f}_{\mathrm{ck}}=30 \mathrm{~N} / \mathrm{mm}^{2} \\
\gamma \mathrm{c}=1,50 \\
\mathrm{f}_{\mathrm{cd}}=\mathrm{f}_{\mathrm{ck}} / \gamma_{\mathrm{c}}=20.0 \mathrm{~N} / \mathrm{mm}^{2} \\
\mathrm{E}=32000 \mathrm{~N} / \mathrm{mm}^{2}\end{array}$ & $\begin{array}{l}\mathrm{f}_{\mathrm{ck}}=30 \mathrm{~N} / \mathrm{mm}^{2} \\
\gamma \mathrm{c}=(1,30-1,50) \\
\mathrm{f}_{\mathrm{cd}}=\mathrm{f}_{\mathrm{ck}} / \gamma_{\mathrm{c}}=20.0 \mathrm{~N} / \mathrm{mm}^{2} \\
\mathrm{E} / 2=16000 \mathrm{~N} / \mathrm{mm}^{2}\end{array}$ \\
\hline $\begin{array}{l}\text { Reinforcement } \\
\text { S-500 }\end{array}$ & $\begin{array}{l}\mathrm{f}_{\mathrm{yk}}=500 \mathrm{~N} / \mathrm{mm}^{2} \\
\gamma_{\mathrm{s}}=1,15 \\
\mathrm{f}_{\mathrm{yd}}=\mathrm{f}_{\mathrm{yk}} / \gamma_{\mathrm{s}}=435 \mathrm{~N} / \mathrm{mm}^{2} \\
\mathrm{E}=200000 \mathrm{~N} / \mathrm{mm}^{2}\end{array}$ & $\begin{array}{l}\mathrm{f}_{\mathrm{yk}}=500 \mathrm{~N} / \mathrm{mm}^{2} \\
\gamma \mathrm{s}=(1,0-1,15) \\
\mathrm{f}_{\mathrm{yd}}=\mathrm{f}_{\mathrm{yk}} / \gamma_{\mathrm{s}}=435 \mathrm{~N} / \mathrm{mm}^{2} \\
E=200000 \mathrm{~N} / \mathrm{mm}^{2}\end{array}$ \\
\hline
\end{tabular}

Table 2. Seismic forces and following parameters

\begin{tabular}{|c|c|c|c|}
\hline Directions & unit & X-X & Y-Y \\
\hline weight & {$[\mathrm{kN}]$} & 70737 & 70737 \\
\hline center of stiffness & {$[\mathrm{m}]$} & 11,843 & 7,90 \\
\hline center of masses & {$[\mathrm{m}]$} & 12,50 & 8,00 \\
\hline static eccentricity & {$[\mathrm{m}]$} & 0,657 & 0,10 \\
\hline accidental eccentricity & {$[\mathrm{m}]$} & 1,250 & 0,80 \\
\hline dynamic eccentricity & {$[\mathrm{m}]$} & 0,873 & 0,10 \\
\hline maximum eccentricity & {$[\mathrm{m}]$} & 2,780 & 1,00 \\
\hline minimum eccentricity & {$[\mathrm{m}]$} & $-0,9215$ & $-0,75$ \\
\hline bending & {$[\lambda]$} & 1,56 & 1,56 \\
\hline torsional radius $\mathrm{r}_{\mathrm{i}}$ & {$[\mathrm{m}]$} & 11,30 & 12,38 \\
\hline Ls & {$[\mathrm{m}]$} & 8,568 & 8,568 \\
\hline $0,30 \mathrm{e}_{\mathrm{oi}}$ & {$[\mathrm{m}]$} & 3,39 & 3,72 \\
\hline $\mathrm{e}_{\mathrm{oi}}$ & {$[\mathrm{m}]$} & 0,657 & 0,10 \\
\hline base acceleration $\mathrm{ag}_{\mathrm{g}}$ & {$\left[\mathrm{m} / \mathrm{s}^{2}\right]$} & $0,25 \mathrm{~g}$ & $0,25 \mathrm{~g}$ \\
\hline fundamental period $\mathrm{T}_{\mathrm{c}}$ & {$[\mathrm{s}]$} & 1,7096 & 1,695 \\
\hline behavior factor & no & 3,00 & 3,00 \\
\hline spectral type & $\mathrm{no}$ & $\mathrm{B}$ & $\mathrm{B}$ \\
\hline spectral ordinate & no & 0,07312 & 0,07375 \\
\hline coefficient $\lambda$ & no & 0,85 & 0,85 \\
\hline factor importance $\gamma_{\mathrm{I}}$ & no & 1,00 & 1,00 \\
\hline base seismic forces & {$[\mathrm{kN}]$} & 4396,50 & 4434,33 \\
\hline
\end{tabular}

Shear control stability and torsion using European code, for designing, are given with the expression shown below: 


$$
\begin{aligned}
& \alpha_{\mathrm{xy}}=\mathrm{h}_{\mathrm{tot}} \cdot \sqrt{\frac{\mathrm{F}_{\mathrm{v}}}{\mathrm{E}_{\mathrm{cm}} \cdot \mathrm{I}_{\mathrm{c}}}} \leq \begin{cases}0,2+0,1 \mathrm{n} & \text { for } \mathrm{n} \leq 3 \\
0,6 & \text { for } \mathrm{n} \geq 4\end{cases} \\
& \alpha_{\mathrm{T}}=\varphi \cdot \mathrm{h}_{\mathrm{tot}} \sqrt{\frac{\mathrm{F}_{\mathrm{v}}}{\mathrm{E}_{\mathrm{cm}} \cdot \mathrm{I}_{\omega}} \cdot\left(\frac{\mathrm{d}^{2}}{12}+\mathrm{c}^{2}\right)} \leq \begin{cases}0,2+0,1 \mathrm{n} & \text { for } \mathrm{n} \leq 3 \\
0,6 & \text { for } \mathrm{n} \geq 4\end{cases}
\end{aligned}
$$

Table3. Control stability in shear and torsion

\begin{tabular}{|c|c|c|c|c|c|}
\hline Loads & & Geometrical data & \multicolumn{3}{|c|}{ Stability control } \\
\hline Permanent & Live & Structure height & $\begin{array}{c}\text { Shear }-\mathrm{x} \\
\text { direction }\end{array}$ & $\begin{array}{c}\text { Shear }-\mathrm{y} \\
\text { direction }\end{array}$ & Torsional \\
\hline $\mathrm{kN} / \mathrm{m}^{2}$ & $\mathrm{kN} / \mathrm{m}^{2}$ & $\mathrm{~m}$ & $\alpha_{\mathrm{x}}$ & $\alpha_{\mathrm{y}}$ & $\alpha_{\mathrm{T}}$ \\
\hline 10.65 & 2.00 & 45.00 & 0.352 & 0.321 & 0.24 \\
\hline
\end{tabular}

Table 4. Distribution of seismic force on the floors of the structure in the direction $\mathrm{x}-\mathrm{x}$

\begin{tabular}{|c|c|c|c|c|c|}
\hline Level & $\begin{array}{c}\mathbf{Z i} \\
(\mathbf{m})\end{array}$ & $\begin{array}{c}\mathbf{W i} \\
(\mathbf{k N})\end{array}$ & $\begin{array}{c}\mathbf{W i Z i} \\
(\mathbf{k N m})\end{array}$ & $\begin{array}{c}\mathbf{F b} \\
(\mathbf{k N})\end{array}$ & $\begin{array}{c}\mathbf{F i} \\
(\mathbf{k N})\end{array}$ \\
\hline $\mathbf{1 5}$ & 45 & 3860.7 & 173731.5 & 4396.5 & 455.07 \\
\hline $\mathbf{1 4}$ & 42 & 4776.88 & 200628.96 & 4396.5 & 525.52 \\
\hline $\mathbf{1 3}$ & 39 & 4776.88 & 186298.32 & 4396.5 & 487.99 \\
\hline $\mathbf{1 2}$ & 36 & 4776.88 & 171967.68 & 4396.5 & 450.45 \\
\hline $\mathbf{1 1}$ & 33 & 4776.88 & 157637.04 & 4396.5 & 412.91 \\
\hline $\mathbf{1 0}$ & 30 & 4776.88 & 143306.4 & 4396.5 & 375.37 \\
\hline $\mathbf{9}$ & 27 & 4776.88 & 128975.76 & 4396.5 & 337.84 \\
\hline $\mathbf{8}$ & 24 & 4776.88 & 114645.12 & 4396.5 & 300.30 \\
\hline $\mathbf{7}$ & 21 & 4776.88 & 100314.48 & 4396.5 & 262.76 \\
\hline $\mathbf{6}$ & 18 & 4776.88 & 85983.84 & 4396.5 & 225.22 \\
\hline $\mathbf{5}$ & 15 & 4776.88 & 71653.2 & 4396.5 & 187.69 \\
\hline $\mathbf{4}$ & 12 & 4776.88 & 57322.56 & 4396.5 & 150.15 \\
\hline $\mathbf{3}$ & 9 & 4776.88 & 42991.92 & 4396.5 & 112.61 \\
\hline $\mathbf{2}$ & 6 & 4776.88 & 28661.28 & 4396.5 & 75.07 \\
\hline $\mathbf{1}$ & 3 & 4776.88 & 14330.64 & 4396.5 & 37.54 \\
\hline Shuma: & & 70737.02 & 1678448.7 & & 4396.50 \\
\hline
\end{tabular}

Table 5. Distribution of seismic force on the floors of the structure in the direction $y-y$

\begin{tabular}{|c|c|c|c|c|c|}
\hline \hline Level & $\begin{array}{c}\mathbf{Z i} \\
(\mathbf{m})\end{array}$ & $\begin{array}{c}\mathbf{W i} \\
(\mathbf{k N})\end{array}$ & $\begin{array}{c}\mathbf{W i Z i} \\
(\mathbf{k N m})\end{array}$ & $\begin{array}{c}\mathbf{F b} \\
(\mathbf{k N})\end{array}$ & $\begin{array}{c}\mathbf{F i} \\
(\mathbf{k N})\end{array}$ \\
\hline $\mathbf{1 5}$ & 45 & 3860.7 & 173731.5 & 4434.33 & 458.99 \\
\hline $\mathbf{1 4}$ & 42 & 4776.88 & 200628.96 & 4434.33 & 530.05 \\
\hline $\mathbf{1 3}$ & 39 & 4776.88 & 186298.32 & 4434.33 & 492.19 \\
\hline $\mathbf{1 2}$ & 36 & 4776.88 & 171967.68 & 4434.33 & 454.33 \\
\hline $\mathbf{1 1}$ & 33 & 4776.88 & 157637.04 & 4434.33 & 416.46 \\
\hline $\mathbf{1 0}$ & 30 & 4776.88 & 143306.4 & 4434.33 & 378.60 \\
\hline $\mathbf{9}$ & 27 & 4776.88 & 128975.76 & 4434.33 & 340.74 \\
\hline $\mathbf{8}$ & 24 & 4776.88 & 114645.12 & 4434.33 & 302.88 \\
\hline $\mathbf{7}$ & 21 & 4776.88 & 100314.48 & 4434.33 & 265.02 \\
\hline $\mathbf{6}$ & 18 & 4776.88 & 85983.84 & 4434.33 & 227.16 \\
\hline $\mathbf{5}$ & 15 & 4776.88 & 71653.2 & 4434.33 & 189.30 \\
\hline $\mathbf{4}$ & 12 & 4776.88 & 57322.56 & 4434.33 & 151.44 \\
\hline $\mathbf{3}$ & 9 & 4776.88 & 42991.92 & 4434.33 & 113.58 \\
\hline $\mathbf{2}$ & 6 & 4776.88 & 28661.28 & 4434.33 & 75.72 \\
\hline $\mathbf{1}$ & 3 & 4776.88 & 14330.64 & 4434.33 & 37.86 \\
\hline Shuma: & & 70737.02 & 1678448.7 & & 4434.33 \\
\hline
\end{tabular}

After the axial value is calculated in vertical elements, such as columns and walls, depending its position and location upon the structure, it results that the value of the axial force on axis A-A and DD have the value $\mathrm{N}_{\mathrm{Ed}}=126,75 \mathrm{kN}$ respectively $\mathrm{N}_{\mathrm{Ed}}=213,0 \mathrm{kN}$, which is lower than $\mathrm{N}_{\mathrm{Ed}, 0.70}$, therefore 
are not taken into calculation, and the number of elements that have impact in the effects of imperfection is equal to 10 .

Table 6. Imperfection phenomena coefficients determination

\begin{tabular}{|c|c|c|c|c|c|c|}
\hline $\boldsymbol{\alpha}_{\mathbf{a} 1}$ & $\sum_{\text {VEd }}(\mathbf{k N})$ & $\mathbf{N}_{\mathbf{E d}, \mathbf{m}}(\mathbf{k N})$ & $\mathbf{n}$ (members) & $\mathbf{N}_{\mathbf{E d}, \mathbf{0 . 7 0}(\mathbf{k N})}$ & $\mathbf{n}$ ' (members) & $\boldsymbol{\alpha}_{\mathbf{n}}$ \\
\hline $5 \cdot 10^{-3}$ & 7486,80 & 440,40 & 17 & 308,28 & 10 & 0.742 \\
\hline
\end{tabular}

Table 7. Presentation of additional impacts from vertical loads upon the structure

\begin{tabular}{|c|c|c|c|c|}
\hline Level & $\begin{array}{c}\mathbf{Z i} \\
(\mathbf{m})\end{array}$ & $\begin{array}{c}\mathrm{Wi} \\
(\mathrm{kN})\end{array}$ & $\theta$ & $\begin{array}{c}\mathrm{Hi} \\
(\mathrm{kN})\end{array}$ \\
\hline 15 & 45 & 3860.7 & \multirow{15}{*}{0.0011} & 4.32 \\
\hline 14 & 42 & 4776.88 & & 5.35 \\
\hline 13 & 39 & 4776.88 & & 5.35 \\
\hline 12 & 36 & 4776.88 & & 5.35 \\
\hline 11 & 33 & 4776.88 & & 5.35 \\
\hline 10 & 30 & 4776.88 & & 5.35 \\
\hline 9 & 27 & 4776.88 & & 5.35 \\
\hline 8 & 24 & 4776.88 & & 5.35 \\
\hline 7 & 21 & 4776.88 & & 5.35 \\
\hline 6 & 18 & 4776.88 & & 5.35 \\
\hline 5 & 15 & 4776.88 & & 5.35 \\
\hline 4 & 12 & 4776.88 & & 5.35 \\
\hline 3 & 9 & 4776.88 & & 5.35 \\
\hline 2 & 6 & 4776.88 & & 5.35 \\
\hline 1 & 3 & 4776.88 & & 5.35 \\
\hline & & & $\sum$ & 79.23 \\
\hline
\end{tabular}

\section{Conclusions}

Based on the results obtained in our study, and not only, but also referring to the contemporary literature, we can emphasize that the structural designers shall be based by the designing codes, in particular EN-1992-1 which it pays more attention to the phenomena of imperfection to the constituent elements of structure. It should be recalled that imperfection takes into account a number of errors which could be done during the time of designing, execution and structure maintenance, especially its impact is at the case of flexible structure, so that horizontal shift are evident and have a significant value as it is the case of structural elements ty pe of skeleton, structural elements from steel especially to those of precast type.

\section{References:}

1. Eurocode 8"Design of structures for earthquake resistance-Part 1"2004

2. Michael N. Fardis Eduardo C. Carvalho Peter Fajfar "Alain PeckerSeismic Design of Concrete Buildings to Eurocode 8” 2015 by Taylor \& Francis Group, LLC

3. GEORGE G. PENELIS and GREGORY G. PENELIS "Concrete Buildings in Seismic Region" 2014

4. MICHAL N. FARDIS " Seismic Design,Assessment and Rretrofitting of Concrete Buildingsbasen on EN-Eurocode 8", Patras Greece 2009

5. Y. ELGHAZOULI," Seismic Design of Buildings to Eurocode 8", London, 2009 
6. ERNEST \& SOHN"Beispiele zur Bemessung nach DIN 1045-1 Band 2- Ingenieurbau", Berlin 2006

7. Prab Bhatt Thomas J. MacGinley Ban Seng Choo "Reinforced Concrete Design to Eurocodes Design Theory and Examples Fourth E d i t i o n"2014

8. Armend Mujaj, Florim Grajçevci, Driton R.Kryeziu "Seismic Analy sis of Structural building with reinforced concrete shear walls according to the European Standards" International Annual Conference Architecture - Spatial Planning and CivilEngineering IC ASPCE 2014, November 7-8, 2014, Durrës, Albania

9. Florim Grajçevci,Armend Mujaj, Zijadin Guri, Driton R.Kry eziu “General criteria of structural control in shear and torsion effects based on required European standards" International Conference on Earthquake Engiand Seismology ISSIZ- Shkup 2015

10. ARMEND MUJAJ "Behavior of Reinforced Concrete Wall System Under the Seismic Action" Master Thesis Prishtina 2012

11. A.GAULKE \& W.KONN"Konstruktiver Ingenieurbau II Stahlbetonbau”, Berlin 2004

12. MUSTAFA HRASNICA“ Seizmicka Analiza Zgrada”Sarajevo 2005

13. EMIR HADŹI-MUSIC்”Aseizmicke Konstrukcije $u$ Visokogradnji” Sarajevo 1985

14. ALFONS GORIS, WIRTSCHAFT SING, GERHARD RICHTER und HELMUT KIRCHNER" Stalbeton und Spannbeton Nach EC 2 Teil 1" Berlin 2000

15. Eurocode 0"Basic of structural design",2002

16. Eurocode 1 "Action on structures "2002

17. Eurocode 2"Design of concrete structures "2004

18. Autodesk Robot Structural Analy sis Professional 2015"

19. The design program "AutoCAD 2009" 